Article

\title{
Effect of Temperature and Concentration of Zeolite Catalysts from Geothermal Solid Waste in Biodiesel Production from Used Cooking Oil by Esterification-Transesterification Process
}

\author{
Luqman Buchori ${ }^{1, *(\mathbb{D}, \text { W. Widayat }}{ }^{1}$, Oki Muraza ${ }^{2}$, Muhamad Iqbal Amali ${ }^{1}$, \\ Rahma Wulan Maulida ${ }^{1}$ and Jedy Prameswari ${ }^{1}$ \\ 1 Department of Chemical Engineering, Faculty of Engineering, Diponegoro University, \\ Semarang 50275, Indonesia; widayat@live.undip.ac.id (W.W.); m.iqbal.amali@gmail.com (M.I.A.); \\ wulanmaulida796@gmail.com (R.W.M.); Jprameswari@gmail.com (J.P.) \\ 2 Department of Chemical Engineering \& Center of Excellence in Nanotechnology (CENT), King Fahd \\ University of Petroleum and Minerals (KFUPM), P.O. Box 5040, Dhahran 31261, Saudi Arabia; \\ omuraza@kfupm.edu.sa \\ * Correspondence: luqman.buchori@che.undip.ac.id; Tel.: +62-878-3219-9466
}

Received: 30 November 2020; Accepted: 8 December 2020; Published: 10 December 2020

\begin{abstract}
The production of biodiesel using zeolite catalysts from geothermal solid waste has been studied. This study aims to make zeolite catalysts as catalysts in biodiesel production, assessing the effect of catalyst concentration, and temperature in the esterification-transesterification process on the biodiesel yield produced. The results showed that the synthesized zeolite catalyst was an analcime zeolite catalyst $\left(\mathrm{Al}_{1.9} \mathrm{Na}_{1.86} \mathrm{O}_{12} \mathrm{Si}_{4}\right)$. The biodiesel yield of $98.299 \%$ with $100 \%$ fatty acid alkyl ester (FAAE) content was achieved at a catalyst concentration of $5 \% \mathrm{wt}$ and a reaction temperature of $300{ }^{\circ} \mathrm{C}$ for one-hour reaction time. The yield of biodiesel decreased with repeated catalysts, which experienced morphological changes before and after three usage times. Consequently, in this case, the catalyst cannot be regenerated.
\end{abstract}

Keywords: analcime zeolite catalyst; biodiesel; geothermal solid waste; used cooking oil; yield of biodiesel

\section{Introduction}

Indonesia's government regulation number 79/2014, concerning the National Energy Policy [1], explains that the cumulatively need for oil, coal, gas, and new renewable energy will increase almost five times between 2015 and 2050. The primary energy supply required in 2025 will be around four hundred million tons of oil equivalent (MTOE), and in 2050, about 1000 MTOE. It is expected that the need for bioenergy will increase (by up to $14 \%$ of the primary energy mix); however, fossil energy, such as petroleum, will still be the dominant energy source [1]. Petroleum-based fuels have adverse impacts on the environment and public health, resulting in an increase in $\mathrm{CO}_{2}$ emissions, the greenhouse effect, and global warming [2]. Therefore, it is necessary to develop environmentally friendly fuels, one of which is biofuels.

One of the most common types of biofuels, as a substitute for diesel, is biodiesel, which can be synthesized from vegetable oil using the cracking method. Biodiesel has advantages over fuel oil, including (1) it can be used directly without engine modification; (2) the dissolved oxygen content can increase engine combustion efficiency; (3) less emission of $\mathrm{CO}$, sulfur, and $\mathrm{NO}$; and (4) it is environmentally friendly [3-5]. Based on a prospective analysis, diesel fuel is one of the fuels that has 
an important role in the Indonesian economy. The blending of biodiesel with diesel was $10 \%$ (B-10) in 2013; it then increased to 20\% (B-20) in 2016 and 30\% in 2020 (B-30) [5]. Therefore, the need for biodiesel is expected to increase significantly.

Used cooking oil contains high levels of FFA and triglycerides caused by repeated use. If this oil waste is disposed of directly into the environment, it will cause turbidity, give off a pungent odor, and (some) will solidify and decompose slowly. Used cooking oil is a derivative of crude palm oil (CPO), rich in organic compounds and carbon, and can be used as a source of energy. Therefore, an intensive study is needed to observe used cooking oil as a potential raw material for biodiesel production [6].

The synthesis of biodiesel using used cooking oil with esterification and transesterification processes has been carried out by several researchers [7-10]. The conventional biodiesel production process has several drawbacks, including inefficient, high methanol consumption, low biodiesel yield, longer reaction time, energy consumption, and high cost [11]. However, several studies have found that the production of biodiesel from waste raw material with heterogeneous catalysts under mild conditions is efficient [12-15]. Nevertheless, the biodiesel production process needs to be studied further to obtain a more efficient process and to overcome other weaknesses from conventional biodiesel production processes.

Geothermal waste is one of the materials that can be used for catalyst synthesis. Several researchers have conducted studies on the use of geothermal waste for catalyst synthesis [16-19]. Doyle et al. [17] studied the comparison between zeolite produced from geothermal waste and conventional silica sol (Ludox). Both catalysts are loaded with Pd and tested in the methane combustion. It was concluded that silica extracted from geothermal waste is successful for zeolite synthesis. Meanwhile, Jaime-Acuña et al. [19] explored the use of geothermal solid waste as a precursor for the synthesis of nanostructured composites with a zeolitic matrix surface. The photocatalytic degradation test of the dye was carried out to determine the best final product. The results show semiconductor/modernite to be the best performance. The catalyst from geothermal sludge used in palm oil transesterification was explored by Perdana et al. [18]. Sodium silicate synthesized from this geothermal sludge was a potential solid base catalyst in biodiesel synthesis. Zeolite synthesized from geothermal waste was studied by Sulardjaka et al. [16] using a hydrothermal process without stirring. The study proves that synthesis of zeolite using geothermal waste with the hydrothermal process is successful.

Geothermal waste from Pembangkit Listrik Tenaga Panas Bumi (PLTPB/Geothermal Power Plant) Geo Dipa Dieng was not utilized and is only disposed of in landfills. If this waste is allowed to form, it will form hardened sediments that can pollute the environment, where the sediment contains a lot of silica [20]. For this reason, an intensive study is needed to develop the potential for geothermal solid waste from PLTPB Geo Dipa Dieng as a raw material for zeolite catalyst synthesis.

The purpose of this research is to produce and characterize zeolite catalysts from geothermal solid waste. The effect of catalyst concentration and temperature of the esterification-transesterification reaction on biodiesel yield was also studied. The catalyst stability test was carried out by operating the catalyst continuously.

\section{Materials and Methods}

\subsection{Materials}

The materials used to produce zeolite catalysts were geothermal solid waste containing $0.09 \%$ $\mathrm{Al}_{2} \mathrm{O}_{3}$ and $75.08 \% \mathrm{SiO}_{2}$ obtained from PT. Geo Dipa, Dieng, Wonosobo, Indonesia. Chemicals with pro-analysis quality (PA) purchased domestically were $\mathrm{Al}(\mathrm{OH})_{3} \cdot \mathrm{xH}_{2} \mathrm{O}$ in powder (containing $50-59 \%$ $\mathrm{Al}_{2} \mathrm{O}_{3}$ and $45 \% \mathrm{Na}_{2} \mathrm{O}$ ) and $\mathrm{NaOH}$ (pa $>98 \%$, pellets). The aquadest used for the catalyst synthesis process was obtained from the Central Laboratory of Research and Services Unit Diponegoro University Integrated Laboratory. The used cooking oil as the raw material was obtained from a fried chicken restaurant in Semarang, Indonesia. 


\subsection{Preparation of Zeolite Catalyst}

Geothermal waste was washed using sanitary water, dried, mashed, and sieved with a size of 40 mesh. A $3 \mathrm{M}$ sodium hydroxide solution was prepared by mixing $24 \mathrm{~g}$ of $\mathrm{NaOH}$ in $200 \mathrm{~mL}$ of water. Fifty grams of geothermal waste was mixed with $20.90 \mathrm{~g}$ of $\mathrm{Al}(\mathrm{OH})_{3}$ and put into a solution of sodium hydroxide. The mixture was stirred using a magnetic stirrer at a speed of $300 \mathrm{rpm}$ until homogeneous. The mixture was then heated at a temperature of $100{ }^{\circ} \mathrm{C}$ for $2 \mathrm{~h}$. Next, it was put into the autoclave reactor for $8 \mathrm{~h}$ at a temperature of $150^{\circ} \mathrm{C}$. The crystalline product formed was washed and neutralized using distilled water to a $\mathrm{pH}$ of $7-8$. The neutralized residue was then dried at room temperature and calcined using steam at a temperature of $550^{\circ} \mathrm{C}$ for $5 \mathrm{~h}$. The catalysts characterization was performed using X-Ray Diffraction (XRD), Scanning Electron Microscopy (SEM)-Energy Dispersive X-ray Spectroscopy (EDX), X-Ray Fluorescence (XRF), and Brunauer-Emmett-Teller (BET) methods.

Characterization using XRD was carried out with the Shimadzu XRD-7000 equipment. XRD patterns were measured at $30 \mathrm{~mA}$ and $40 \mathrm{kV}$ under $\mathrm{Cu}-\mathrm{K} \alpha$ radiation conditions at $\mathrm{k}=1.54 \AA$. The diffraction pattern was observed at an angle of $2 \theta$ from 10 to $90^{\circ}$ with a step time of $0.5 \mathrm{~s}$. The data obtained were then processed using match software (Match Copyright 2003-2016 Crystal Impact, Bonn, Germany-Phase Analysis Report) to find the components of the peak intensity.

Characterization using Scanning Electron Microscopy-Energy Dispersive of X-ray Spectroscopy (SEM-EDX) was performed to determine the surface structure (morphology) and the component of the catalyst. The catalyst morphology was characterized by SEM JEOL JSM6510LA.

$\mathrm{X}$-ray fluorescence (XRF) is used to determine the composition of the elements in the sample. $\mathrm{XRF}$ analysis was performed using the Rigaku Supermini200. The instrument is equipped with a Benchtop tube under a sequential wavelength dispersive X-ray fluorescence (WDXRF) spectrometer.

The BET method is used to estimate the surface area. Characterization was carried out using the ChemBET PULSAR Quantachrome apparatus using the Nitrogen adsorption-desorption method at $-195.8^{\circ} \mathrm{C}(77.35 \mathrm{~K})$. Samples were degassed at $300^{\circ} \mathrm{C}(573.15 \mathrm{~K})$ for $5 \mathrm{~h}$ under vacuum pressure $\left(6.58 \times 10^{-5} 1\right.$ /Torr $)$ prior to adsorption measurement.

\subsection{Biodiesel Production}

The research was conducted through two experiments. In the first experiment, $3000 \mathrm{~mL}$ of used cooking oil was filtered to remove impurities. Used cooking oil filtrate resulting from the filtration process was a raw material used for biodiesel production. Three hundred milliliters of used cooking oil filtrate, $25 \%$ wt of methanol, and zeolite catalyst were introduced into the reactor. The zeolite catalyst was varied at $1,2,3,4$, and $5 \% \mathrm{wt}$, respectively. The reactor was heated using a heater that was controlled and measured by a temperature controller and connected to an electric tube furnace. The reactor was then heated to a temperature of $300{ }^{\circ} \mathrm{C}$ and held at this temperature. The esterification-transesterification process was conducted for $1 \mathrm{~h}$ after the temperature was reached. The biodiesel produced from each variable was then analyzed using (Gas Chromatography-Mass Spectrometry (GCMS) (QP2010S SHIMADZU, DB-1 column). The maximum yield of \% by weight of catalyst generated from experiment 1 was used as a fixed variable in experiment 2 . The second experiment was carried out by varying the reaction temperature at $200{ }^{\circ} \mathrm{C}, 220^{\circ} \mathrm{C}, 240{ }^{\circ} \mathrm{C}, 260{ }^{\circ} \mathrm{C}$, $280^{\circ} \mathrm{C}$, and $300{ }^{\circ} \mathrm{C}$. Biodiesel produced from each variable in the esterification-transesterification process was analyzed using GCMS.

The physicochemical properties of used cooking oil and biodiesel standards are presented in Table 1. 
Table 1. The physicochemical properties of used cooking oil and biodiesel standards.

\begin{tabular}{cccc}
\hline Properties & Unit & Used Cooking Oil & $\begin{array}{c}\text { Biodiesel Standard } \\
\text { (SNI No. 7182-2015) }\end{array}$ \\
\hline Boiling point & ${ }^{\circ} \mathrm{C}$ & 175 & n.d. \\
Flash point & ${ }^{\circ} \mathrm{C}$ & 314 & Minimum 100 \\
Density & $\mathrm{kg} / \mathrm{m}^{3}$ & 944 & $850-890$ \\
Viscosity & $\mathrm{mm}^{2} / \mathrm{s}$ & 30.182 & $2.3-6.0$ \\
\hline
\end{tabular}

SNI = Standar Nasional Indonesia (Indonesian National Standard); n.d. = not determined.

\subsection{Reusability Catalyst}

The zeolite catalyst was used three times to study the stability and effect of repeated use of the synthesized catalyst. This study was conducted at an operating temperature of $300^{\circ} \mathrm{C}$, the weight ratio of used cooking oil: alcohol of 4:1, the reaction time of $60 \mathrm{~min}$, and the catalyst concentration of $5 \% \mathrm{wt}$. After being used for the reaction, the catalyst was washed using n-hexane at room temperature without any treatment. In response, the biodiesel yield and catalyst morphology were observed through SEM analysis.

\subsection{Biodiesel Yield}

The yield was the ratio of the product obtained and the raw materials used. In this case, the yield of biodiesel was the ratio of the mass of the product (biodiesel) and the mass of the feed (used cooking oil). The yield of biodiesel is expressed in Equation (1).

$$
\text { Yield }_{\text {biodiesel }}=\frac{\text { weight of biodiesel }(\mathrm{g})}{\text { weight of feed }(\mathrm{g})}
$$

\subsection{Biodiesel Density}

The biodiesel density analysis was carried out by weighing the empty pycnometer expressed as $w_{1}$ (gram) and the pycnometer containing biodiesel as $w_{2}$ (gram). The biodiesel density is calculated using Equation (2),

$$
\text { density }(\rho)=\frac{w_{1}-w_{2}}{V}
$$

where $V$ is the pycnometer volume in $\mathrm{mL}$.

\subsection{Biodiesel Viscosity}

The viscosity of biodiesel was determined using the Ostwald viscosimeter. First, the Ostwald viscosimeter was filled with $15 \mathrm{~mL}$ of distilled water. Distilled water was sucked with a rubber hose until the distilled water surface exceeded the upper limit which is defined as $\mathrm{s}_{1}$. Next, let the distilled water flowed freely. The stopwatch was turned on when distilled water was right at the upper limit line $\left(s_{1}\right)$, and the stopwatch was turned off when distilled water was right at the bottom line which is defined as $\mathrm{s}_{2}$. The time taken by distilled water was recorded. This step was repeated to obtain the viscosity of the biodiesel. The viscosity of biodiesel is calculated by Equation (3):

$$
\eta_{x}=\frac{\rho_{x} \cdot t_{x}}{\rho_{a} \cdot t_{a}} \eta_{a}
$$

where $\eta_{x}=$ viscosity of biodiesel; $\eta_{a}=$ viscosity of distilled water; $\rho_{x}=$ biodiesel density; $\rho_{a}=$ density of distilled water, $t_{x}=$ time taken by biodiesel; $t_{a}=$ time taken by distilled water. 


\section{Results and Discussions}

\subsection{Synthesis of Zeolite from Geothermal Solid Waste}

Zeolite catalyst was synthesized using geothermal solid waste from PT. Geo Dipa, Dieng-Wonosobo, Central Java. The synthesis was carried out by hydrothermal and calcination methods. Before use, the impurities in the waste were removed using distilled water. The clean waste content was analyzed using EDX. The metal oxide content of the waste is presented in Table 2.

Table 2. Energy Dispersive X-ray Spectroscopy (EDX) test results on the chemical composition of the geothermal waste (this research (a); Riyanto et al. [21] (b); Fitriyana et al. [22] (c); Sulardjaka et al. [16] (d)).

\begin{tabular}{ccccc}
\hline \multirow{2}{*}{ Compounds } & \multicolumn{5}{c}{ \% Mass } \\
\cline { 2 - 5 } & $\mathbf{a}$ & $\mathbf{b}$ & $\mathbf{c}$ & $\mathbf{d}$ \\
\hline $\mathrm{Al}_{2} \mathrm{O}_{3}$ & 0.09 & 2.01 & 0.06 & 0.08 \\
$\mathrm{SiO}_{2}$ & 75.08 & 55.23 & 49.10 & 77.70 \\
\hline
\end{tabular}

Two main elements, $\mathrm{SiO}_{2}$ and $\mathrm{Al}_{2} \mathrm{O}_{3}$, are parameters for the feasibility of utilizing geothermal waste in the zeolite synthesis process [23]. The synthesis of zeolite is very sensitive to feedstock properties, especially from silica and alumina sources. Silica can influence many aspects of zeolite crystallization, including crystal growth kinetics and product properties. The application of different silica sources greatly affects the results of the synthesis experiment [24]. In this research, 35\%wt of zeolite was obtained from geothermal waste. Based on chemical composition data, geothermal solid waste has the potential to be synthesized into zeolites.

The elemental composition of the geothermal waste and synthesized zeolite has been analyzed using X-Ray Fluorescence (XRF) and the results are presented in Table 3.

Table 3. Results of X-Ray Fluorescence (XRF) analysis of the geothermal waste and synthesized zeolite.

\begin{tabular}{ccc}
\hline Component & Geothermal Waste (\% Mass) & Synthesized Zeolite (\% Mass) \\
\hline $\mathrm{Al}$ & 0.0759 & 2.2312 \\
$\mathrm{Si}$ & 29.9671 & 5.3533 \\
$\mathrm{P}$ & 0.0225 & 3.7641 \\
$\mathrm{~S}$ & 0.0592 & 4.8824 \\
$\mathrm{Cl}$ & 0.0514 & 6.7222 \\
$\mathrm{~K}$ & 0.1357 & 8.1671 \\
$\mathrm{Ca}$ & 0.0667 & 6.6745 \\
$\mathrm{Fe}$ & 0.2044 & 9.3304 \\
$\mathrm{Cu}$ & 0.0138 & 1.4825 \\
$\mathrm{Zn}$ & 0.0589 & 1.8796 \\
$\mathrm{As}$ & 0.0099 & 3.0953 \\
$\mathrm{Sb}$ & 0.0434 & 2.0411 \\
\hline
\end{tabular}

Based on the results of XRF analysis, the highest impurity in geothermal waste was Fe, while other elements were concluded to be negligible due to the very small amount detected. Iron ( $\mathrm{Fe}$ ) is a common metal found in the geothermal waste and was present partly due to dissolved iron from carbon steel piping and brine handling equipment in the geothermal plant [25]. The presence of iron in the waste would not affect the zeolite synthesis, as it would be irreversibly self-reduced into $\mathrm{Fe}^{2+}$ atoms when zeolite activation (calcination) took place later in the reaction [26].

The XRD characterization used to determine the crystallinity and purity levels of the geothermal waste and synthesized zeolite is shown in Figure 1. 


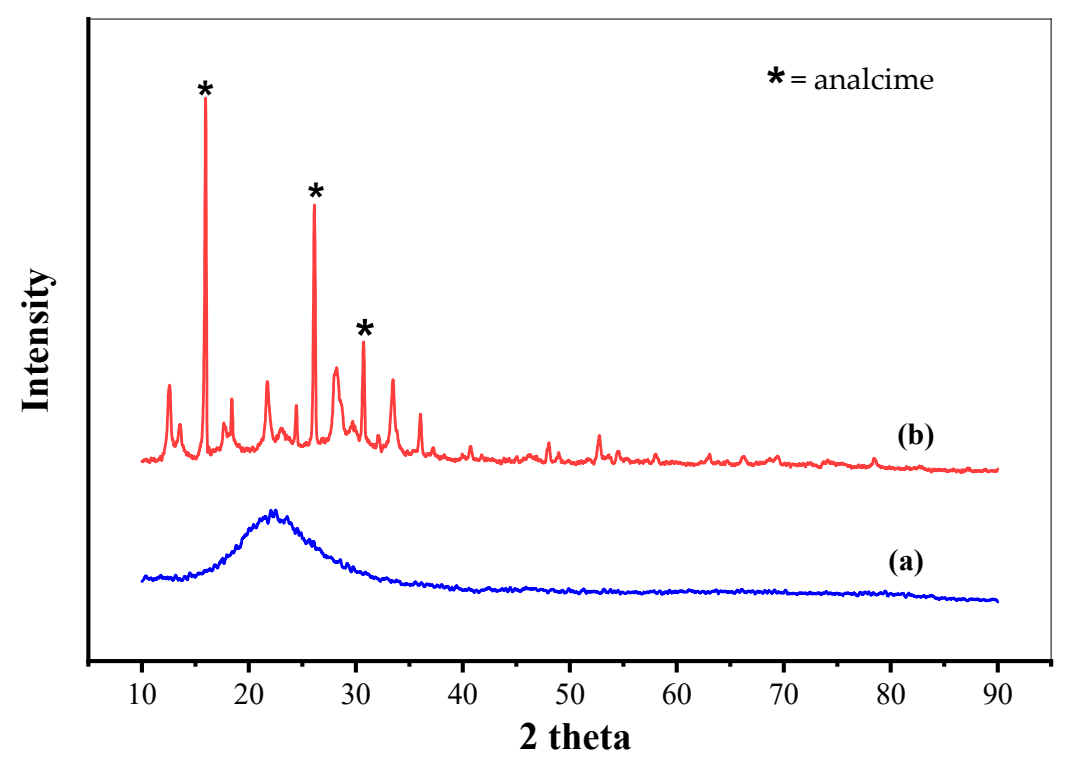

Figure 1. Diffractogram of (a) geothermal waste and (b) synthesized zeolite from geothermal waste.

As shown in Figure 1, the geothermal waste used in this research was amorphous, indicated by the lack of sharp peaks present in the diffractogram result. In contrast, the synthesized zeolite catalyst diffractogram shows that the position of the peak intensity point is observed at a certain $2 \theta$. The synthesized zeolite has many sharp peaks as shown on the diffractogram, indicating that it was more crystal than to the geothermal waste. It could also be concluded that the zeolite has been successfully synthesized from the geothermal waste, due to the significant increase in crystallinity from amorphous to crystalline and complete change of the peaks and patterns between them.

Based on the diffractogram pattern and the use of match software, the highest peak intensities of the synthesized zeolite were observed at $15.977,26.123$, and $30.717^{\circ}$. It indicates that the catalyst has a tetragonal crystal system. All of the highest peaks showed an analcime $\left(\mathrm{Al}_{1.9} \mathrm{Na}_{1.86} \mathrm{O}_{12} \mathrm{Si}_{4}\right)$ diffraction pattern (The International Centre for Diffraction Data (ICDD) No. 00-044-01030).

Other information obtained from the above diffractogram, based on the analysis using match software: analcime crystals have cell parameters a $=13.6251 \AA$ and $\mathrm{c}=13.5870 \AA$ and a density of 2.112 $\mathrm{g} / \mathrm{mL}$ with a tetragonal crystal system. The synthetic zeolite structure has the general formula $\mathrm{M}_{\mathrm{x} / \mathrm{n}}$ $\left[\left(\mathrm{AlO}_{2}\right)_{\mathrm{x}}\left(\mathrm{SiO}_{2}\right)_{\mathrm{y}}\right]_{\cdot \mathrm{w}} \mathrm{H}_{2} \mathrm{O}$ [27], where $\mathrm{M}$ is an alkaline or alkaline earth cation, $\mathrm{n}$ is the number of valence cations, $\mathrm{w}$ is the number of water molecules per unit cell, $\mathrm{x}$ and $\mathrm{y}$ is the amount of tetrahedra alumina silicate in the unit cell, while the ratio of $y / x$ or $\mathrm{SiO}_{2} / \mathrm{Al}_{2} \mathrm{O}_{3}$ is the acidity of zeolite. Based on the XRF analysis results in Table 3, the $\mathrm{Si} / \mathrm{Al}$ ratio obtained is 2.39. This result is in accordance with the study conducted by Chen et al. [28] who obtained the $\mathrm{Si} / \mathrm{Al}$ ratio of 2.0.

Compared to the diffractogram pattern of analcime zeolite catalysts synthesized from the stem of sorghum Halepenesic ash extract [29], the highest peak intensity points were observed at 16.0, 26.0, and $30.5^{\circ}$. It can be concluded that the zeolite characterization of the diffractogram pattern does not have a significant difference. Therefore, according to the experimental results, the zeolite synthesized from geothermal solid waste is analcime zeolite.

Morphology plays an important role in catalyst activity and selectivity. Figure 2 presents SEM analysis results in the form of zeolite catalyst morphology with a magnification of 10,000×. Figure 2 shows the morphology of stacked sheet-like structures, repetitive, and having a book with a tetragonal crystal shape. According to Verboekend et al. [30], zeolite crystal formation occurs in hydrothermal processes. In this research, the hydrothermal process was conducted by adding heat at $150{ }^{\circ} \mathrm{C}$ for $8 \mathrm{~h}$ to form a more regular arrangement. 


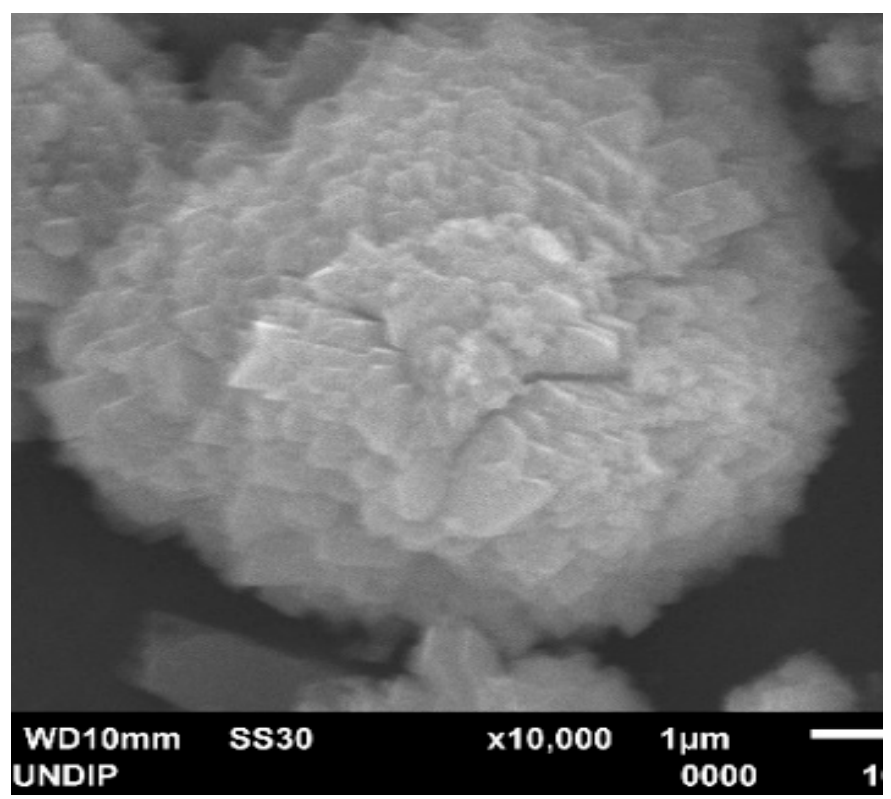

Figure 2. SEM analysis of zeolite catalyst.

Based on the SEM analysis, it has been established that zeolites are aluminosilicate crystals. Besides being influenced by $\mathrm{Si}-\mathrm{Al}$ and $\mathrm{OH}$ content, the formation of aluminosilicate crystals in this study was also carried out by adding $3 \mathrm{M} \mathrm{NaOH}$ solution. The addition of $\mathrm{NaOH}$ solution functions to reduce the amorphous phase and increase the crystal phase. In addition, it also acts as an activator by activating the silica and aluminum components found in geothermal waste to form water-soluble aluminates and silicate salts, which then play a role in the formation of zeolites during the hydrothermal process [31]. The addition of $\mathrm{NaOH}$ solution made the solution alkaline $(\mathrm{pH}>12)$ to polymerize zeolite to form ions. The zeolite skeletal ions are $\mathrm{Si}(\mathrm{OH})_{4}{ }^{-}$as crystalline silica and anion $\mathrm{Al}(\mathrm{OH})_{4}{ }^{-}$, which is derived from the alumina source.

Figure 2 also shows that calcination of the silica-alumina at a temperature of $550{ }^{\circ} \mathrm{C}$ for $5 \mathrm{~h}$ affects the morphology of the catalyst. Si and Al can be evenly dispersed on the surface because water and impurities on the surface can be removed. Calcination is the physical activation of the catalyst by hot air or a vacuum system to release water molecules.

Table 4 presents the results of the BET analysis regarding the specific surface area of the synthesized zeolite, before and after calcination.

Table 4. The specific surface area of the synthesized zeolite resulted from the Brunauer-Emmett-Teller (BET) analysis.

\begin{tabular}{cccc}
\hline \multirow{2}{*}{ Properties } & \multirow{2}{*}{ Unit } & \multicolumn{2}{c}{ Synthesized Zeolite } \\
\cline { 3 - 4 } & & Before Calcination & After Calcination \\
\hline Surface Area & $\mathrm{m}^{2} / \mathrm{g}$ & 99.525 & 244.465 \\
\hline
\end{tabular}

In this study, calcination at a temperature of $550{ }^{\circ} \mathrm{C}$ for $5 \mathrm{~h}$ affects the surface area of the catalyst produced because it can remove water and unwanted liquid (impurities) in the zeolite, which is left in the pores of the material, thereby increasing the surface area of the zeolite [32]. Table 4 shows that if the catalyst were calcined at a higher temperature $\left(550^{\circ} \mathrm{C}\right)$ it would increase the surface area quite significantly. 


\subsection{Conversion of Used Cooking Oil to Biodiesel}

Biodiesel is produced from used cooking oil. Used cooking oil, before it is used as raw material, is filtered first to remove impurities. Used cooking oil, cleaned from impurities, was analyzed by GCMS to determine the components of its constituent compounds. The composition of used cooking oil as a result of the analysis was then compared with the results of an experiment conducted by Syam et al. [33] and Banani et al. [34], and is presented in Table 5.

Table 5. Results of Gas Chromatography-Mass Spectrometry (GCMS) analysis of used cooking oil.

\begin{tabular}{cccc}
\hline Compounds & This Study (\%wt) & Syam et al. [33] (\%wt) & Banani et al. [34] (\%wt) \\
\hline Dodecanoic acid & 0.59 & 35.36 & - \\
Tetradecanoid acid & 0.97 & 24.68 & - \\
9-Hexadecenoic acid & 0.63 & 1.17 & - \\
Hexadecanoic acid & 34.74 & 12.53 & 28.85 \\
9,12-Octadecadienoic & 11.82 & - & 29.83 \\
acid & 46.72 & 8.32 & 4.87 \\
9-Octadecenoic acid & 4.19 & 4.63 & - \\
Octadecanoic acid & 0.34 & - & - \\
Eicosanoic acid & - & 6.18 & - \\
Octanoic & - & 7.13 & 2.49 \\
Decanoic & - & - & \\
9,12,15-Octadecatrienoic & & & \\
acid & & &
\end{tabular}

The results of the GCMS analysis in Table 5 show the differences in fatty acid composition. The amount of fatty acid composition in used cooking oil depends on the frequency of use and the type of material fried in the oil.

Table 5 shows that the GCMS analysis results of used cooking oil in this study have the highest acid content, namely 9-Octadecenoic acid, which is included in oleic acid. The used cooking oil used in this study is a vegetable oil derived from CPO. Generally, vegetable oils contain $90-98 \%$ triglycerides [35]. It means that used cooking oil has the potential as a raw material for biodiesel production. The characteristics of used cooking oil include density and viscosity, $944 \mathrm{~kg} / \mathrm{m}^{3}$ and $30.182 \mathrm{~mm}^{2} / \mathrm{s}$, respectively.

Biodiesel production is conducted by an esterification-transesterification process using a zeolite catalyst. The biodiesel content produced in this study is shown in Table 6.

According to the International Agency for Research on Cancer (IARC) [36], diesel fuel consists of hydrocarbons with a $\mathrm{C}_{9}-\mathrm{C}_{20}$ carbon chain. Based on Table 6, the hydrocarbons formed are types of diesel oil $\left(C_{9}-C_{20}\right)$ and heavy hydrocarbons $\left(>C_{20}\right)$. Table 6 shows that the percentage of biodiesel containing hydrocarbons $>C_{20}$ is very small, namely $0.54 \%$ in the form of Hexadecanoic acid, 2-hydroxy-1,3-propannediyl ester. The other, which is the main component, is diesel oil products $\left(\mathrm{C}_{9}-\mathrm{C}_{20}\right)$. The compound of Hexadecanoic acid, 2-hydroxy-1,3-propanediol ester $\left(\mathrm{C}_{35} \mathrm{H}_{68} \mathrm{O}_{5}\right)$ is an ester bonding compound with an $\mathrm{OH}$ group in the second chain. 
Table 6. The results of the GCMS analysis of biodiesel products.

\begin{tabular}{|c|c|c|c|}
\hline Compounds & Molecular Formulas & Composition (\%) & Chemical Structure \\
\hline Tetradecanoic acid, ethyl ester (CAS) & $\mathrm{C}_{16} \mathrm{H}_{32} \mathrm{O}_{2}$ & 1.19 & \\
\hline Hexadecanoic acid, methyl ester (CAS) & $\mathrm{C}_{17} \mathrm{H}_{34} \mathrm{O}_{2}$ & 2.58 & \\
\hline Decanoic acid, ethyl ester (CAS) & $\mathrm{C}_{12} \mathrm{H}_{24} \mathrm{O}_{2}$ & 35.49 & \\
\hline 9-Octadecenoic acid, methyl ester (CAS) & $\mathrm{C}_{19} \mathrm{H}_{36} \mathrm{O}_{2}$ & 52.03 & \\
\hline Linoleic acid ethyl ester & $\mathrm{C}_{20} \mathrm{H}_{36} \mathrm{O}_{2}$ & 3 & \\
\hline Octadecanoic acid, ethyl ester (CAS) & $\mathrm{C}_{20} \mathrm{H}_{40} \mathrm{O}_{2}$ & 4.31 & \\
\hline $\begin{array}{c}\text { Hexadecanoic acid, } \\
\text { 2-hydroxy-1,3-propannediyl ester (CAS) }\end{array}$ & $\mathrm{C}_{35} \mathrm{H}_{68} \mathrm{O}_{5}$ & 0.54 & \\
\hline Heptadecanoic acid, ethyl ester (CAS) & $\mathrm{C}_{19} \mathrm{H}_{38} \mathrm{O}_{2}$ & 0.34 & \\
\hline
\end{tabular}


The results obtained in this study were better than those of other researchers who used zeolites as catalysts. In a study conducted by Hartono et al. [37], using Banten Bayah natural zeolite modified with potassium hydroxide, the yield of biodiesel was 94\%. Meanwhile, Al-Jamal et al. [38] used zeolite tuff impregnated with $\mathrm{KOH}$ for biodiesel production and provided a maximum biodiesel yield of 96.7\%. Ramos et al. [39] used zeolite catalysts (mordenite, beta, and X) to produce biodiesel from sunflower oil. The yield of methyl esters ranged between 93.5 and $95.1 \%$. The use of Fe/zeolite catalyst from geothermal waste was carried out by Muna et al. [40]. The highest biodiesel yield was obtained at $87.8 \%$. The yield of biodiesel produced in this study was $98.29 \%$. This result is higher than that of biodiesel produced by several other researchers. In addition, the advantage of this research is that the resulting product does not contain glycerol, so that it can produce a high yield and purity of biodiesel.

The density and viscosity of the biodiesel produced from the esterification-transesterification process were measured and compared with the Indonesian National Standard (SNI). The results are presented in Tables 7 and 8 .

Table 7. Biodiesel density and viscosity at various catalyst concentrations.

\begin{tabular}{cccccc}
\hline \multirow{2}{*}{ Parameter } & \multicolumn{5}{c}{ Catalyst Concentration $(\mathbf{\%} \mathbf{w t})$} \\
\cline { 2 - 6 } & $\mathbf{1}$ & $\mathbf{2}$ & $\mathbf{3}$ & $\mathbf{4}$ & $\mathbf{5}$ \\
\hline Density $\left(\mathrm{kg} / \mathrm{m}^{3}\right)$ & 851 & 853 & 858 & 861 & 865 \\
Viscosity $\left(\mathrm{mm}^{2} / \mathrm{s}\right)$ & 4.713 & 4.742 & 4.871 & 4.939 & 5.150 \\
\hline
\end{tabular}

Table 8. Biodiesel density and viscosity at various temperatures.

\begin{tabular}{cccccc}
\hline \multirow{2}{*}{ Parameter } & \multicolumn{5}{c}{ Temperature $\left({ }^{\circ} \mathrm{C}\right)$} \\
\cline { 2 - 6 } & $\mathbf{2 0 0}$ & $\mathbf{2 2 0}$ & $\mathbf{2 4 0}$ & $\mathbf{2 6 0}$ & $\mathbf{2 8 0}$ \\
\hline Density $\left(\mathrm{kg} / \mathrm{m}^{3}\right)$ & 887 & 880 & 876 & 871 & 867 \\
Viscosity $\left(\mathrm{mm}^{2} / \mathrm{s}\right)$ & 5.918 & 5.827 & 5.702 & 5.468 & 5.216 \\
\hline
\end{tabular}

Based on Tables 7 and 8, the biodiesel density and viscosity obtained have different values for each variable. The biodiesel density and viscosity obtained in this study have good quality because they fulfill the SNI biodiesel standards (SNI No. 7182-2015). According to SNI, the density is $850-890 \mathrm{~kg} / \mathrm{m}^{3}$ and a maximum viscosity of $6 \mathrm{~mm}^{2} / \mathrm{s}$ [41].

According to Kouzu et al. [42], the reaction between 1 mole of triglycerides and 3 moles of alcohol will produce three moles of biodiesel and one mole of glycerol, as shown in Figure 3. The formation of biodiesel and glycerol from triglycerides requires excess alcohol.

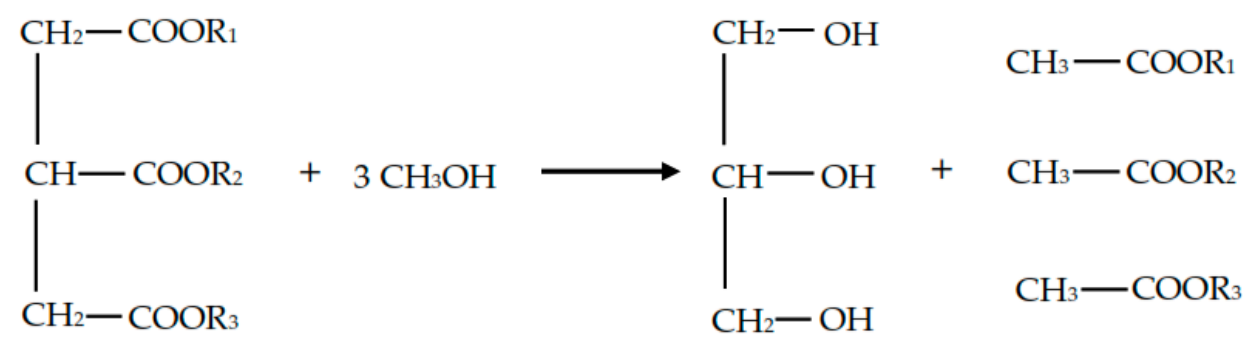

\section{$\begin{array}{llll}\text { Triglyceride } & 3 \text { Alcohol } & \text { Glycerol } & \text { Biodiesel }\end{array}$}

Figure 3. Triglyceride reaction with an alcohol.

In this study, glycerol compounds were not produced, but instead, there was the formation of a hexadecanoic acid, 2-hydroxy-1,3-propanediol ester $\left(\mathrm{C}_{35} \mathrm{H}_{68} \mathrm{O}_{5}\right)$, which is an ester bond compound 
with the $\mathrm{OH}$ group in the second chain. It can be interpreted that the reaction mechanism that occurs between triglycerides and alcohol does not follow Figure 3. In this study, the reactions that occur follow other reaction mechanisms, as shown in Figure 4.

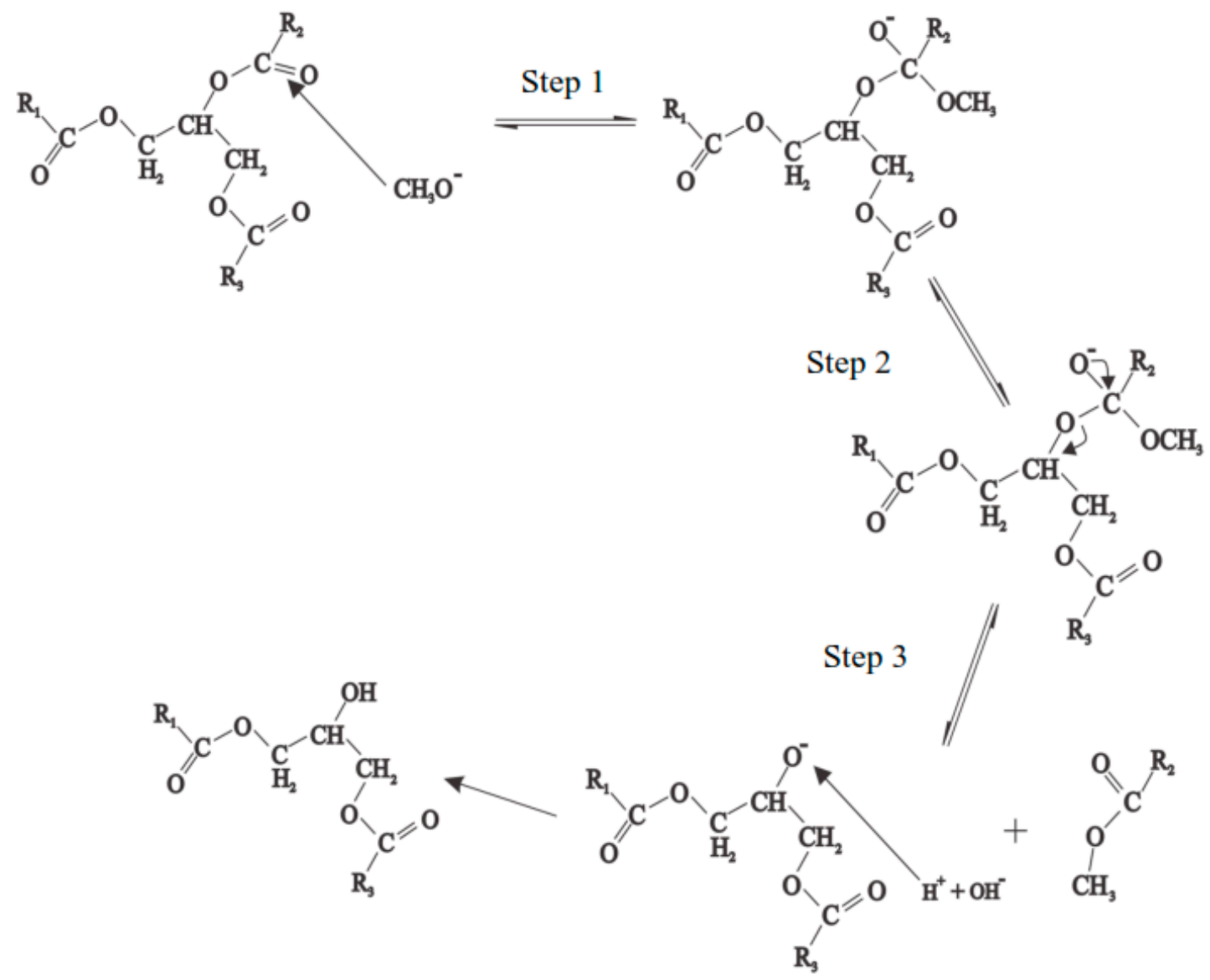

Figure 4. Triglyceride reaction with alcohol (this study).

The proposed mechanism was the basic active site of $\mathrm{CH}_{3} \mathrm{O}^{-}$directly attacked the triglyceride's second palmitic chain, causing the double bond to break and formed an ester bond. Next, the second palmitic chain will be broken down due to the nucleophilic attack on the carbon atom, leaving only the first and third chain of the triglyceride intact. Rearrangement of the chain will take place, followed by the addition of $\mathrm{H}^{+}$proton forming FAME and diglyceride molecule. Due to the lack of $\mathrm{OH}^{-}$bond formed, glycerol was not completely formed as evidenced by the GCMS results.

This can occur from one of the possibilities, namely the addition of a little alcohol or used cooking oil raw materials that are not suitable. The triglycerides are not completely cut and separated into glycerol and biodiesel. Based on the calculation of mass balance with the weight ratio of used cooking oil: alcohol is $4: 1$, and the yield is $98.29 \%$, then every 0.3 moles of triglycerides will react with 1.5 moles of alcohol. If the triglycerides are used up reacting with excess methanol, it takes $315 \mathrm{~mL}$ of used cooking oil and $87 \mathrm{~mL}$ of alcohol. In this case, the used cooking oil is not suitable, causing the alcohol to not react completely with the triglycerides. To ascertain the direction of the chemical reactions that occur, further research is needed by carrying out nuclear magnetic resonance (NMR) spectroscopic analysis.

\subsection{Effect of Catalyst Concentration on Biodiesel Yield}

The research was conducted at $300^{\circ} \mathrm{C}$ for $1 \mathrm{~h}$ with the catalyst concentration of $1,2,3,4$, and $5 \%$ wt. The results are presented in Figure 5. 


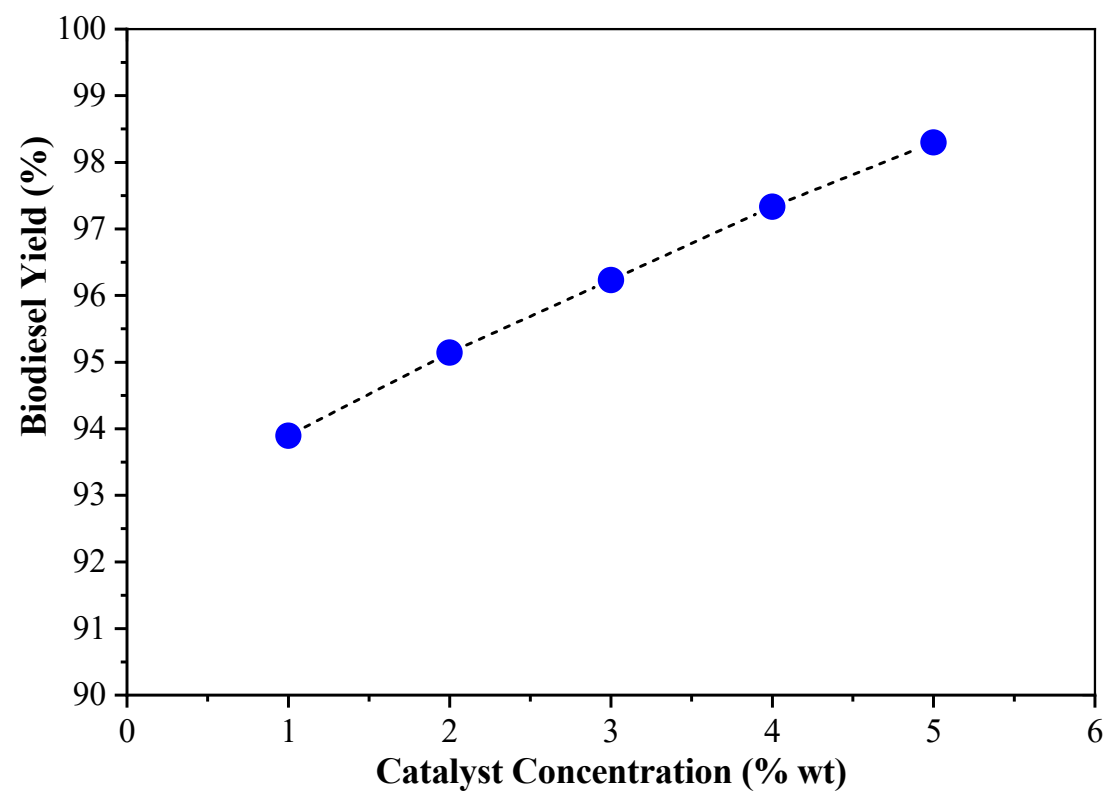

Figure 5. Effect of catalyst concentration on biodiesel yield.

Figure 5 indicates that the biodiesel yield increases with increasing catalyst concentration in the esterification-transesterification process. The yield of biodiesel obtained was 93.895, 95.143, 96.234, 97.334 , and $98.299 \%$ at a catalyst concentration of $1,2,3,4$, and $5 \% \mathrm{wt}$, respectively. The more catalyst used, the active site of the catalyst used as a reaction site will also increase. In this case, the number of catalysts that can provide adsorption to break the $\mathrm{OH}$ bond in methanol is also increasing. Therefore, the methanol is easily broken down into methoxide ions and hydrogen cations. The methoxide ion in the catalyst reacts with triglyceride molecules to form biodiesel [43].

\subsection{Effect of Temperature on Biodiesel Yield}

The research was carried out at $200,220,240,260,280$, and $300{ }^{\circ} \mathrm{C}$ with a catalyst concentration of $5 \% \mathrm{wt}$ and a reaction time of $1 \mathrm{~h}$. The research results are presented in Figure 6.

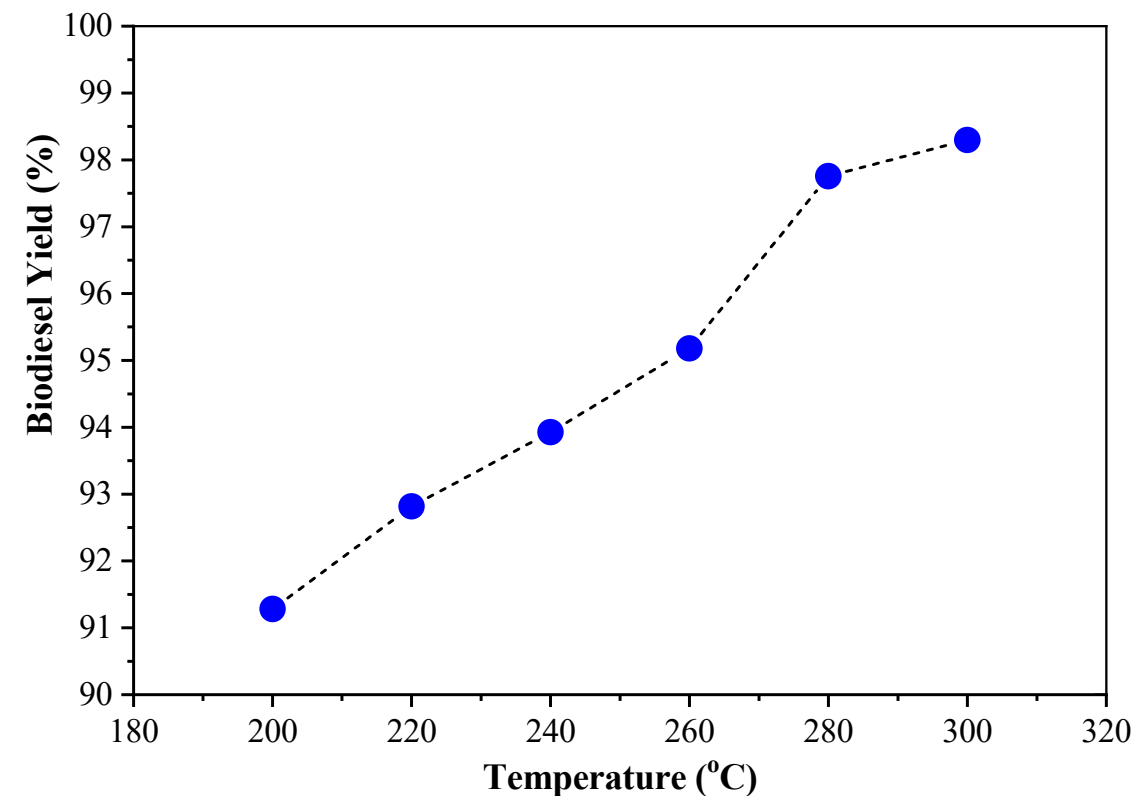

Figure 6. Effect of temperature on biodiesel yield. 
Figure 6 shows that the yield of biodiesel increases with increasing temperature in the esterification-transesterification process. The yield of biodiesel obtained was 91.282, 92.817, $93.929,95.179,97.756$, and $98.299 \%$ at a reaction temperature of $200,220,240,260,280$, and $300{ }^{\circ} \mathrm{C}$, respectively. Catalyst activity increases with increasing operating temperature in the reactor. Increasing the activity of this catalyst will increase the yield of biodiesel [44].

\subsection{Reusability Catalyst}

The zeolite catalyst was used three times to study the stability and effect of repeated use of the synthesized catalyst. The operating conditions were kept constant, namely the operating temperature of $300^{\circ} \mathrm{C}$, the weight ratio of used cooking oil: alcohol was $4: 1$, the reaction time of $60 \mathrm{~min}$, and the catalyst concentration of $5 \% \mathrm{wt}$. After being used for the reaction, the catalyst was simply washed using n-hexane at room temperature without any treatment. In response, the biodiesel yield will be observed. The biodiesel yield is presented in Figure 7.

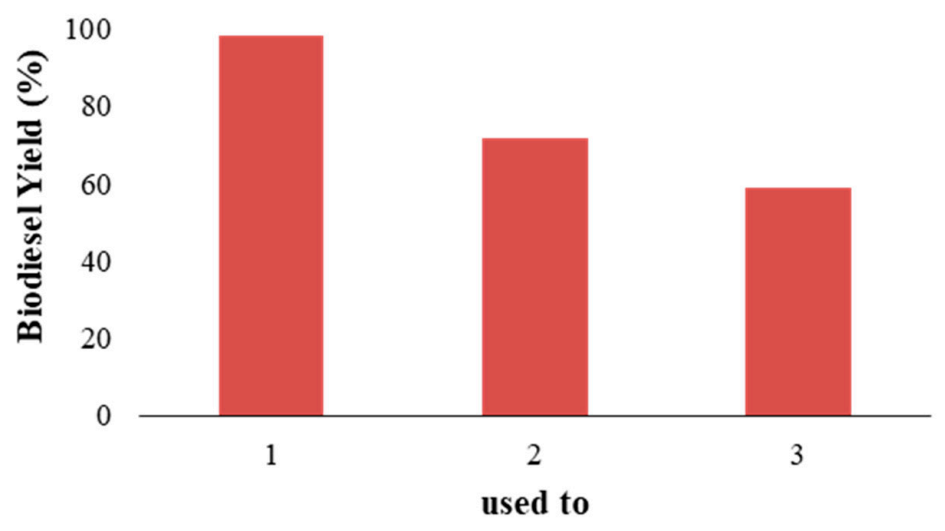

Figure 7. Biodiesel yield at several times the use of a catalyst.

In Figure 7, it can be seen that, in the first usage, the biodiesel yield is $98.299 \%$, it is $71.56 \%$ in the second use, and $58.95 \%$ by the third use. This decrease is due to the decreased reactivity or ability of the zeolite catalyst in the esterification-transesterification process with repeated use of the catalyst.

Another result is shown through the analysis of catalyst morphology. As shown in Figure 8, the catalyst shape changes compared to Figure 2. Before use, the zeolite catalyst is shaped like a sheet of stacked books, and after three uses, it is shaped like a separate square flake. The change in shape in the morphology of the catalyst after repeated use can be caused by the release of active components [45]. In this case, it can be concluded that the catalyst cannot be regenerated.

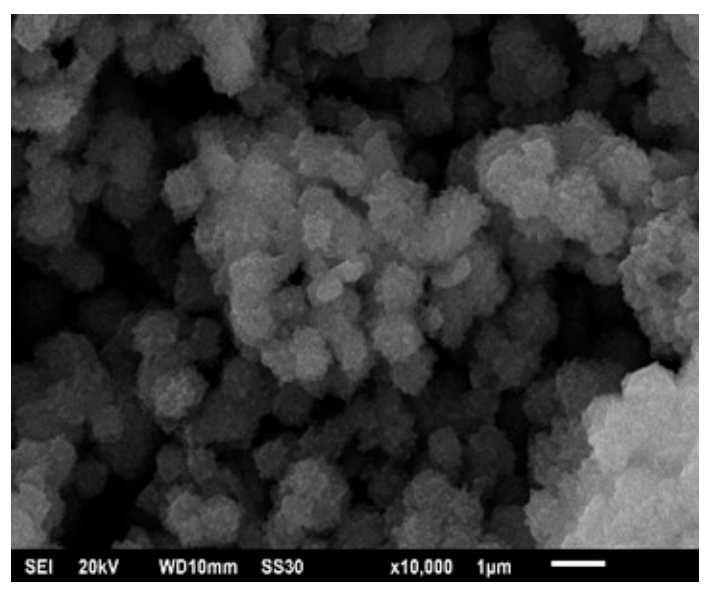

Figure 8. SEM analysis of catalyst after 3x usage. 


\section{Conclusions}

The results showed that the catalyst synthesized from the geothermal solid waste was the analcime zeolite catalyst $\left(\mathrm{Al}_{1.9} \mathrm{Na}_{1.86} \mathrm{O}_{12} \mathrm{Si}_{4}\right)$ with a tetragonal crystal system. The synthesis of zeolite from geothermal solid waste can significantly increase the crystallinity from amorphous to crystalline. Meanwhile, calcination at $550{ }^{\circ} \mathrm{C}$ could increase the surface area of the catalyst. The surface area of the catalyst obtained was $244.465 \mathrm{~m}^{2} / \mathrm{g}$. The $\mathrm{Si} / \mathrm{Al}$ ratio of the synthesized zeolites was found to be 2.39 .

The yield of biodiesel increased with the catalyst concentration increase due to the increase in the active site presence for the reaction. On the other hand, the biodiesel yields also increased with the temperature increase as the catalyst activity increases with increasing operating temperature in the reactor. The highest yield of biodiesel was obtained at a catalyst concentration of $5 \% \mathrm{wt}$ and a temperature of $300{ }^{\circ} \mathrm{C}$ for one hour of reaction, which is $98.299 \%$ with $100 \%$ FAAE. The biodiesel yield decreased with repeated use of the catalyst, which experienced morphological changes before and after use three times, so that, in this case, the catalyst cannot be regenerated.

Author Contributions: Conceptualization, L.B., W.W., and O.M.; methodology, L.B.; formal analysis, L.B., W.W.; investigation, M.I.A.; resources, R.W.M.; data curation, J.P.; writing-original draft preparation, L.B.; writing-review and editing, W.W. and O.M.; visualization, M.I.A, R.W.M., and J.P.; supervision, L.B.; project administration, L.B. and J.P. All authors have read and agreed to the published version of the manuscript.

Funding: This research was funded by Ministry of Research and Technology through the Konsorsium Riset Unggulan Perguruan Tinggi (Higher Education Leading Research Consortium) with the research contract number: 201-05/UN7.6.1/PP/2020.

Conflicts of Interest: The authors declare no conflict of interest.

\section{References and note}

1. Peraturan Pemerintah Republik Indonesia No. 79 tahun 2014 tentang Kebijakan Energi Nasional (National Energy Policy, Government Regulation No. 79/2014. Indonesia, 2014).

2. Singh, H.K.A.P.G.; Yusup, S.; Wai, C.K. Physicochemical properties of crude rubber seed oil for biogasoline production. Procedia Eng. 2016, 148, 426-431. [CrossRef]

3. Buchori, L.; Istadi, I.; Purwanto, P. Advanced chemical reactor technologies for biodiesel production from vegetable oils-A review. Bull. Chem. React. Eng. Catal. 2016, 11, 406-429. [CrossRef]

4. Singh, D.; Sharma, D.; Soni, S.L.; Sharma, S.; Sharma, P.K.; Jhalani, A. A review on feedstocks, production processes, and yield for different generations of biodiesel. Fuel 2020, 262, 116553. [CrossRef]

5. Kusmiyati, K.; Prasetyoko, D.; Murwani, S.; Fadhilah, M.N.; Oetami, T.P.; Hadiyanto, H.; Widayat, W.; Budiman, A.; Roesyadi, A. Biodiesel production from reutealis trisperma oil using $\mathrm{KOH}$ impregnated eggshell as a heterogeneous catalyst. Energies 2019, 12, 3714. [CrossRef]

6. Pertamina. Biofuel development the world's hope of renewable energy. Energia 2020, January, 12-30.

7. Tsai, J.-H.; Chen, S.-J.; Huang, K.-L.; Lin, W.-Y.; Lin, C.-C.; Ding, J.-Y.; Yang, C.-H.; Chiu, J.-Y.; Chiu, C.-H. Characteristics of exhaust emissions of a diesel generator fueled with water-containing butanol and waste-edible-oil-biodiesel blends. Aerosol Air Qual. Res. 2015, 15, 2129-2139. [CrossRef]

8. Chung, Z.L.; Tan, Y.H.; Chan, Y.S.; Kansedo, J.; Mubarak, N.M.; Ghasemi, M.; Abdullah, M.O. Life cycle assessment of waste cooking oil for biodiesel production using waste chicken eggshell derived $\mathrm{CaO}$ as catalyst via transesterification. Biocatal. Agric. Biotechnol. 2019, 21, 101317. [CrossRef]

9. Tan, Y.H.; Abdullah, M.O.; Kansedo, J.; Mubarak, N.M.; Chan, Y.S.; Nolasco-Hipolito, C. Biodiesel production from used cooking oil using green solid catalyst derived from calcined fusion waste chicken and fish bones. Renew. Energy 2019, 139, 696-706. [CrossRef]

10. Putra, M.D.; Irawan, C.; Udiantoro; Ristianingsih, Y.; Nata, I.F. A cleaner process for biodiesel production from waste cooking oil using waste materials as a heterogeneous catalyst and its kinetic study. J. Clean. Prod. 2018, 195, 1249-1258. [CrossRef]

11. Widayat, W.; Hadiyanto, H.; Purbaningdyah, E.; Suryanto, I.; Budiman, A.; Roesyadi, A.; Kusmiyati, K. Production of biodiesel from waste cooking oil using heterogeneous catalysts $\mathrm{KI} / \gamma-\mathrm{Al}_{2} \mathrm{O}_{3}$. J. Environ. Eng. Sci. 2020, 15, 107-112. [CrossRef] 
12. Melero, J.A.; Bautista, L.F.; Morales, G.; Iglesias, J.; Sánchez-Vázquez, R. Biodiesel production from crude palm oil using sulfonic acid-modified mesostructured catalysts. Chem. Eng. J. 2010, 161, 323-331. [CrossRef]

13. Morales, G.; Bautista, L.F.; Melero, J.A.; Iglesias, J.; Sánchez-Vázquez, R. Low-grade oils and fats: Effect of several impurities on biodiesel production over sulfonic acid heterogeneous catalysts. Bioresour. Technol. 2011, 102, 9571-9578. [CrossRef]

14. Iglesias, J.; Melero, J.A.; Bautista, L.F.; Morales, G.; Sánchez-Vázquez, R. Continuous production of biodiesel from low grade feedstock in presence of Zr-SBA-15: Catalyst performance and resistance against deactivation. Catal. Today 2014, 234, 174-181. [CrossRef]

15. Melero, J.A.; Bautista, L.F.; Morales, G.; Iglesias, J.; Sánchez-Vázquez, R. Acid-catalyzed production of biodiesel over arenesulfonic SBA-15: Insights into the role of water in the reaction network. Renew. Energy 2015, 75, 425-432. [CrossRef]

16. Sulardjaka, S.; Fitriyana, D.F.; Adi, A.P. Synthesis of zeolite from geothermal waste. Appl. Mech. Mater. 2014, 660, 157-161. [CrossRef]

17. Doyle, A.M.; Postolache, R.; Shaw, D.; Rothon, R.; Tosheva, L. Methane oxidation over zeolite catalysts prepared from geothermal fluids. Microporous Mesoporous Mater. 2019, 285, 56-60. [CrossRef]

18. Perdana, I.; Nugrahanti, N.; Sofiyah; Bendiyasa, I.M. Transesterification of palm oil using sodium silicate base catalyst from geothermal sludge. IOP Conf. Ser. Mater. Sci. Eng. 2016, 162, 1-7. [CrossRef]

19. Jaime-Acuña, O.E.; Villavicencio-García, H.; Vázquez-González, R.; Petranovskii, V.; Raymond-Herrera, O. Synthesis of nanostructured metal-, semiconductor-, and metal/semiconductor-mordenite composites from geothermal waste. J. Appl. Res. Technol. 2016, 14, 232-238. [CrossRef]

20. Wangi, I.P.; Perdana, I. Geothermal-sludge-based sodium silicate catalyst deactivation in methyl ester production process. J. Indones. Food Nutr. Prog. 2019, 16, 22-26. [CrossRef]

21. Riyanto, N.; Sumardi, P.C.; Perdana, I. Recovery of microamorphous silica from Dieng's geothermal sludge via sol-gel extraction. In Proceedings of the 17th Regional Symposium on Chemical Engineering (RSCE 2010), Bangkok, Thailand, 22-23 November 2010.

22. Fitriyana, D.F.; Sulardjaka, S.; Norman, I.; Dzulfikar, M.D.M. Pengaruh suhu hydrothermal terhadap karakteristik zeolit yang disintesis dari limbah geothermal. Momentum 2018, 14, 46-50.

23. Munfarida, S.; Widayat, W.; Satriadi, H.; Cahyono, B.; Hadiyanto; Philia, J.; Prameswari, J. Geothermal industry waste-derived catalyst for enhanced biohydrogen production. Chemosphere 2020, 258, 1-8. [CrossRef]

24. Yusof, A.M.; Nizam, N.A.; Rashid, N.A.A. Hydrothermal conversion of rice husk ash to faujasite-types and NaA-type of zeolites. J. Porous Mater. 2010, 17, 39-47. [CrossRef]

25. Gallup, D.L.; Reiff, W.M. Characterization of geothermal scale deposits by Fe-57 Mössbauer spectroscopy and complementary x-ray diffraction and infra-red studies. Geothermics 1991, 20, 207-224. [CrossRef]

26. Starokon, E.V.; Dubkov, K.A.; Pirutko, L.V.; Panov, G.I. Mechanisms of iron activation on Fe-containing zeolites and the charge of $\alpha$-oxygen. Top. Catal. 2003, 23, 137-143. [CrossRef]

27. Gatta, G.D.; Lotti, P. Chapter 1-Systematics, crystal structures, and occurrences of zeolites. In Micro and Nano Technologies, Modified Clay and Zeolite Nanocomposite Materials; Mercurio, M., Sarkar, B., Langella, A., Eds.; Elsevier: Amsterdam, The Netherlands, 2019; pp. 1-25. [CrossRef]

28. Chen, J.; Ma, H.; Liu, C.; Yuan, J. Synthesis of analcime crystals and simultaneous potassium extraction from natrolite syenite. Adv. Mater. Sci. Eng. 2017, 2017, 1-9. [CrossRef]

29. Azizi, S.N.; Ghasemi, S.; Derakhshani-Mansoorkuhi, M. The synthesis of analcime zeolite nanoparticles using silica extracted from stem of sorghum Halepenesic ash and their application as support for electrooxidation of formaldehyde. Int. J. Hydrogen Energy 2016, 41, 21181-21192. [CrossRef]

30. Verboekend, D.; Nuttens, N.; Locus, R.; van Aelst, J.; Verolme, P.; Groen, J.C.; Perezramirez, J.; Sels, B.F. Synthesis, characterisation, and catalytic evaluation of hierarchical faujasite zeolites: Milestones, challenges, and future directions. Chem. Soc. Rev. 2016, 45, 3331-3352. [CrossRef]

31. Jiang, J.; Feng, L.; Gu, X.; Qian, Y.; Gu, Y.; Duanmu, C. Synthesis of zeolite A from palygorskite via acid activation. Appl. Clay Sci. 2012, 55, 108-113. [CrossRef]

32. Dipowardani, B.T.; Sriatun, S.; Taslimah, T. Sintesis silika kristalin menggunakan surfaktan cetiltrimetilamonium bromida (CTAB) dan trimetilamonium klorida (TMACl) sebagai pencetak pori. J. Kim. Sains Apl. 2008, 11, 20-28. [CrossRef]

33. Syam, A.M.; Maulinda, L.; Ibrahim, I.; Muhammad, S. Waste frying oils-based biodiesel: Process and fuel properties. Smart Grid Renew. Energy 2013, 4, 281-286. [CrossRef] 
34. Banani, R.; Youssef, S.; Bezzarga, M.; Abderrabba, M. Waste frying oil with high levels of free fatty acids as one of the prominent sources of biodiesel production. J. Mater. Environ. Sci. 2015, 6, 1178-1185.

35. Siram, K.; Habibur Rahman, S.M.; Balakumar, K.; Duganath, N.; Chandrasekar, R.; Hariprasad, R. Chapter 4-Pharmaceutical nanotechnology: Brief perspective on lipid drug delivery and its current scenario. In Biomedical Applications of Nanoparticles, Grumezescu, A.M., Ed.; William Andrew Publishing: Norwich, NY, USA, 2019; pp. 91-115. [CrossRef]

36. International Agency for Research on Cancer. Occupational Exposures in Petroleum Refining; Crude on and Major Petroleum Fuels. In IARC Monograph on the Evaluation of Carcinogenic Risks to Humans, 1st ed.; IARC: Lyon, France, 1989; Volume 45, pp. 1-390.

37. Hartono, R.; Wijanarko, A.; Hermansyah, H. Modification of Bayah Banten natural zeolite as heterogeneous catalyst in biodiesel production. J. Appl. Eng. Sci. 2019, 17, 431-438. [CrossRef]

38. Al-Jammal, N.; Al-Hamamre, Z.; Alnaief, M. Manufacturing of zeolite-based catalyst from zeolite tuft for biodiesel production from waste sunflower oil. Renew. Energy 2016, 93, 449-459. [CrossRef]

39. Ramos, M.J.; Casas, A.; Rodríguez, L.; Romero, R.; Pérez, Á. Transesterification of sunflower oil over zeolites using different metal loading: A case of leaching and agglomeration studies. App. Cat. A Gen. 2008, 346, 79-85. [CrossRef]

40. Muna, N.L.; Mualimah, A.A.; Pridiana, D.B.; Widodo, A.K.; Adiyar, S.R.; Elinda, E.H. The production of biodiesel from waste cooking oil (Simultaneous esterification and transesterification using Fe/zeolite catalysts from waste geothermal). Mater. Sci. Forum 2020, 990, 161-167. [CrossRef]

41. Devaraj, K.; Veerasamy, M.; Aathika, S.; Mani, Y.; Thanarasu, A.; Dhanasekaran, A.; Subramanian, S. Study on effectiveness of activated calcium oxide in pilot plant biodiesel production. J. Clean. Prod. 2019, 225, 18-26. [CrossRef]

42. Kouzu, M.; Kasuno, T.; Tajika, M.; Sugimoto, Y.; Yamanaka, S.; Hidaka, J. Calcium oxide as a solid base catalyst for transesterification of soybean oil and its application to biodiesel production. Fuel 2008, 87, 2798-2806. [CrossRef]

43. Atadashi, I.M.; Aroua, M.K.; Abdul Aziz, A.R.; Sulaiman, N.M.N. The effects of catalysts in biodiesel production: A review. J. Ind. Eng. Chem. 2013, 19, 14-26. [CrossRef]

44. Farooq, M.; Ramli, A.; Naeem, A. Biodiesel production from low FFA waste cooking oil using heterogeneous catalyst derived from chicken bones. Renew. Energy 2015, 76, 362-368. [CrossRef]

45. Zhu, S.; Gao, X.; Dong, F.; Zhu, Y.; Zheng, H.; Li, Y. Design of a highly active silver-exchanged phosphotungstic acid catalyst for glycerol esterification with acetic acid. J. Catal. 2013, 306, 155-163. [CrossRef]

Publisher's Note: MDPI stays neutral with regard to jurisdictional claims in published maps and institutional affiliations.

(C) 2020 by the authors. Licensee MDPI, Basel, Switzerland. This article is an open access article distributed under the terms and conditions of the Creative Commons Attribution (CC BY) license (http://creativecommons.org/licenses/by/4.0/). 